\title{
Auxin-binding proteins without KDEL sequence in the moss Funaria hygrometrica
}

\author{
Kishore C. S. Panigrahi • Madhusmita Panigrahy • \\ Marco Vervliet-Scheebaum • Daniel Lang $\cdot$ Ralf Reski • \\ Man Mohan Johri
}

Received: 22 July 2009/Revised: 4 September 2009/Accepted: 16 September 2009/Published online: 2 October 2009

(C) The Author(s) 2009. This article is published with open access at Springerlink.com

\begin{abstract}
Whereas the important plant growth regulator auxin has multiple effects in flowering plants, it induces a specific cell differentiation step in the filamentous moss protonema. Here, we analyse the presence of classical auxin-binding protein (ABP1) homologues in the moss Funaria hygrometrica. Microsomal membranes isolated from protonemata of $F$. hygrometrica have specific indole acetic acid-binding sites, estimated to be about 3-5 pmol/ $\mathrm{mg}$ protein with an apparent dissociation constant $\left(K_{\mathrm{d}}\right)$ between 3 and $5 \mu \mathrm{M}$. Western analyses with anti-ABP1 antiserum detected the canonical endoplasmic reticulum (ER)-localised 22-24 kDa ABP1 in Zea mays, but not in F. hygrometrica. Instead, polypeptides of $31-33$ and $46 \mathrm{kDa}$ were labelled in the moss as well as in maize. In $F$. hygrometrica these proteins were found exclusively in
\end{abstract}

Communicated by P. Kumar.

K. C. S. Panigrahi $(\bowtie)$

Max-Plank Institute for Plant Breeding Research,

Carl-von-Linne-Weg 10, 50829 Cologne, Germany

e-mail: panigrah@mpiz-koeln.mpg.de

M. Panigrahy

Directorate of Rice Research, Rajendranagar, Hyderabad,

Andhra Pradesh 500028, India

M. Vervliet-Scheebaum · D. Lang · R. Reski

Plant Biotechnology, Faculty of Biology, University of Freiburg,

Schaenzlestrasse 1, 79104 Freiburg, Germany

R. Reski

Centre for Biological Signalling Studies (bioss),

University of Freiburg, Albertstrasse 19,

79104 Freiburg, Germany

M. M. Johri

32 New Cosmos, Juhu-Versova Link Road, Andheri (W),

Mumbai 400053, India microsomal membrane fractions and were confirmed as ABPs by photo-affinity labelling with 5 -azido- $\left[7-{ }^{3} \mathrm{H}\right]-$ indole-3-acetic acid. Unlike the classical corn ABP1, these moss ABPs did not contain the KDEL ER retention sequence. Consistently, the fully sequenced genome of the moss Physcomitrella patens, a close relative of $F$. hygrometrica, encodes an ABP1-homologue without KDEL sequence. Our study suggests the presence of putative ABPs in $F$. hygrometrica that share immunological epitopes with $\mathrm{ABP} 1$ and bind auxin but are different from the classical corn ABP1.

Keywords ABP1 - Photo-affinity labelling · Phytohormone $\cdot$ Physcomitrella patens $\cdot$ Signalling .

Zea mays

\author{
Abbreviations \\ IAA Indole-3-acetic acid \\ ER Endoplasmic reticulum
}

\section{Introduction}

Changes in the development of land plants are usually regulated by phytohormones (Davies 1995). Auxin, as the most prominent one, acts as growth regulator thus being involved in a variety of developmental and physiological processes in a tissue specific manner such as specification of root and shoot, cell elongation and cell division (Weijers and Jurgens 2005; Willemsen and Scheres 2004). Auxin is ubiquitous in heterotrophic and photoautotrophic organisms; besides from seed plants, its presence has been confirmed in algae, bryophytes and ferns (Evans and Trewavas 1991). In algae and 
fungi, auxin is produced and detectable as secondary metabolite, although its function in these organisms is not yet known. The role of auxin as plant hormone in early land plants has been documented starting from the bryophytes (Cooke et al. 2002; Johri 2004, 2008; Paponov et al. 2009; Sztein et al. 1999, 2000). The filamentous, tip-growing protonemata of the closely related mosses Funaria hygrometrica and Physcomitrella patens have been extensively studied to understand the role of phytohormones in cell differentiation (Johri 1974; Decker et al. 2006). The protonema consists of two distinct cell types, the chloronema and the caulonema. Chloronema cells have more chloroplasts and are separated by a straight septum whereas caulonema cells have fewer plastids and oblique cross walls (Johri 1974; Reski 1998). In addition, chloronema cells are mainly arrested in the G2/M phase of the cell cycle, whereas caulonema cells are mainly arrested in G1/S (Schween et al. 2003). Similar to flowering plants, an auxin gradient exists in the moss protonema with maxima in the most actively dividing cells (Bierfreund et al. 2003).

Auxin evokes two responses in Funaria protonema: at a low level it inhibits chloronema proliferation, while at higher levels it enhances secondary caulonema differentiation (Johri and Desai 1973). Both responses are antagonised by the anti-auxin $p$-chlorophenoxyisobutyric acid (PCIB) (Johri and D'Souza 1990). PCIB reduces polar, basipetal auxin transport in Funaria rhizoids (Rose and Bopp 1983) and was reported to impair the auxin-signalling pathway by reducing the stability of auxin/indole-3acetic acid (Aux/IAA) gene transcripts in Arabidopsis roots (Oono et al. 2003). Thus, both basipetal transport and IAAbinding sites seem to be involved during caulonema differentiation and chloronema inhibition (Johri 2004). In addition, cell division is inhibited, if auxin efflux from Physcomitrella protoplasts is blocked by napthylphtalamic acid (NPA) (Bhatla et al. 2002).

It is known from flowering plants that parts of the multiple auxin responses are mediated by the nuclear auxin receptor TRANSPORT INHIBITOR RESPONSE 1 (TIR1) (Dharmasiri et al. 2005; Kepinski and Leyser 2005) which, upon binding of auxin, degrades AUXIN/INDOLE-3ACETIC ACID (Aux/IAA)-proteins (Dharmasiri and Estelle 2002), releasing the inhibitory effect on auxin response factors (ARFs), transcription factors that in turn regulate auxin responsive gene expression (Quint and Gray 2006; Benjamins and Scheres 2008). It is, however, evident that not all auxin responses are regulated via this nuclear receptor (Badescu and Napier 2006).

Thus, another important mediator of auxin action may be ABP1, an auxin-binding protein involved in cell expansion (Jones et al. 1998), and subsequently found in a variety of seed plants by affinity labelling (Christian et al. 2003; Napier et al. 2002). ABP1 is a $22-24 \mathrm{kDa}$ protein from corn which is localised predominantly in the endoplasmic reticulum (ER), as it possesses a C-terminal KDEL ER retention sequence (Henderson et al. 1997; Jones and Herman 1993; Woo et al. 2002). A smaller fraction of this protein is secreted outside and located in the outer leaflet of the plasma membrane (Jones and Herman 1993; Oliver et al. 1995). ABP1 has been shown to mediate the hyperpolarization response and stomatal opening stimulated by auxin (Barbier-Brygoo et al. 1992; Christian et al. 2003, Leblanc et al. 1999; Gehring et al. 1998) and to be involved in cell cycle control (David et al. 2007). Other investigations have proposed a role of ABP1 in directional root growth (Shimomura 2006).

The current study aimed at characterising proteins in the protonema of moss $F$. hygrometrica homologous to ABP1 of Zea mays. To this end a radioactive IAA-binding assay was employed to determine if moss microsomes contained specific auxin-binding sites. To further investigate specific ABPs, biochemical, immunological and photo-affinity labelling approaches were used. The results presented here reveal the presence of specific ABPs in Funaria. Antibodies specific to corn ABP1 could detect polypeptides of 31-33 and $46 \mathrm{kDa}$, respectively. However, unlike ABP1 of corn, both these polypeptides did not contain epitopes of the classical KDEL ER retention sequence. Similar results were obtained when nucleotide sequences from other mosses homologous to the ABP1 of maize were compared as shown for $P$. patens and Ceratodon purpureus. We therefore propose that the non-ER localised ABPs of Funaria, and probably in all mosses, play a role in the regulation of auxin responses during the differentiation of moss protonema.

\section{Materials and methods}

\section{Plant material}

The protonema of $F$. hygrometrica Hedw. (cell line J-2) and dark grown coleoptiles of corn (Z. mays L.) were used in the present study. Chloronema cells of Funaria were grown in liquid suspension cultures as described earlier (Johri 1974). Cells grown in minimal medium supplemented with glucose (MMG) were harvested at a cell density of $4-5 \mathrm{mg} / \mathrm{ml}$ and used fresh or kept frozen until used. Hybrid corn seeds (variety MMH 65, from Maharastra Hybrid Seeds, Mumbai, India) were germinated on moist, autoclaved vermiculite and the coleoptiles (approximately $1.5 \mathrm{~cm}$ from the tips) were harvested and used for the experiment.

\section{Microsomes for $\left[{ }^{3} \mathrm{H}\right]$-IAA binding}

Two grams of freshly harvested protonema cells were homogenised in an ice-cold mortar and pestle in the 
presence of acid washed sand ( $0.25 \mathrm{~g}$ sand per $\mathrm{g}$ cells) for $45 \mathrm{~min}$ in a buffer containing $250 \mathrm{mM}$ sucrose, $7 \mathrm{mM}$ citrate buffer $\mathrm{pH} 5.5$ and $5 \mathrm{mM}$ magnesium chloride $\left(\mathrm{MgCl}_{2}\right)$ (2.5 vol per gram fresh weight of cells). The crude homogenate was filtered through two layers of nylon cloth and the filtrate was centrifuged at $10,000 \times g$ for $30 \mathrm{~min}$ using a Kubota RA 400 rotor. The supernatant was then centrifuged at $110,000 \times g$ for $45 \mathrm{~min}$ using a SW $41 \mathrm{Ti}$ swing-out rotor to obtain the microsomal pellet. The microsomes were resuspended in binding buffer containing $7 \mathrm{mM}$ citrate and $5 \mathrm{mM} \mathrm{MgCl} \mathrm{pH}_{2} 5.5$ and dialysed overnight against $0.7 \mathrm{mM}$ citrate buffer and $0.5 \mathrm{mM}$ $\mathrm{MgCl}_{2}$ with four changes of buffer. The dialysed samples were centrifuged at $10,000 \times g$ to eliminate any precipitate and used to determine binding of radioactively labelled auxin in the filter assay.

\section{Auxin-binding assay}

The assay was performed in the dark at $4^{\circ} \mathrm{C}$ in a final volume of $160 \mu \mathrm{l}$ solution containing $7 \mathrm{mM}$ citrate buffer pH 5.5, $5 \mathrm{mM} \mathrm{MgCl}_{2}, 83 \mathrm{nM}{ }^{3} \mathrm{H}$-IAA, $20 \mu \mathrm{l}$ of microsomal proteins $(10 \mu \mathrm{g})$. The samples were incubated for $30 \mathrm{~min}$ and the bound radioactivity was displaced by incubating with increasing amounts of non-radioactive IAA $(1 \mathrm{nM}-100 \mu \mathrm{M})$ for $30 \mathrm{~min}$ on ice. After the incubation, $44 \mu \mathrm{l}$ of the reaction mixture were filtered through cellulose acetate filters under vacuum. The filters were washed with $20 \mathrm{ml}$ washing buffer $(0.7 \mathrm{mM}$ citrate buffer $\mathrm{pH} 5.5$ and $0.5 \mathrm{mM} \mathrm{MgCl}$ ), dried and the radioactivity retained on the filters was determined using PPO (poly $p$-phenylene oxide), and POPOP [1, 4-bis (5-phenyloxazol-2-yl) benzene], a toluene based scintillant. Each concentration was tested in triplicate and the mean value was plotted against the radioactivity retained on the filter.

Sub-cellular fractionation for immuno-detection of ABPs and electron microscopy analysis

The sub-cellular fractionation of the crude extract was performed under cold conditions. Five grams of frozen moss protonema or corn coleoptiles were homogenised, suspended in grinding buffer [GB: $250 \mathrm{mM}$ sucrose, $20 \mathrm{mM}$ (2-Amino-2-hydroxymethyl-propane-1,3-diol) Tris- $\mathrm{HCl} \mathrm{pH}$ 8.0, $1 \mathrm{mM}$ ethylenediaminetetraacetic acid (EDTA), $1 \mathrm{mM}$ dithiothreitol (DTT)] with a mixture of protease inhibitors, antipain, leupeptin, chymostatin, pepstatin and tosyl phenylalanyl chloromethyl ketone (TPCK) at a final concentration of $50 \mu \mathrm{M}$ and kept in ice for $15 \mathrm{~min}$. The homogenates were filtered through two layers of nylon cloth and the filtrate was further fractionated by differential centrifugation. Successive centrifugation of the filtrates at $5,000 \times g$ for $10 \mathrm{~min}, 35,000 \times g$ for $30 \mathrm{~min}$ and
$110,000 \times g$ for $1 \mathrm{~h}$, resulted in three pellets $(\mathrm{P} 1, \mathrm{P} 2, \mathrm{P} 3)$ and a supernatant $(\mathrm{S})$, respectively. The pellets were washed two times with GB and resuspended in the GB containing $1 \%$ sodium cholate and kept for $30 \mathrm{~min}$ on ice with occasional vortexing and centrifuged at the respective $g$ forces to eliminate the particulate insoluble material. The resulting supernatant was used in the experiments. To isolate the total solubilised protein, sodium cholate was added dropwise to the filtrate in order to obtain a final concentration of $1 \%$. This suspension was further incubated for $30 \mathrm{~min}$ and centrifuged at $35,000 \times g$ for $15 \mathrm{~min}$ to extract and use the supernatant. The protein content was estimated using the Bradford dye-binding assay, denatured by boiling in Laemmli sample buffer containing $62 \mathrm{mM}$ Tris pH 6.8, 10\% Glycerol, 2\% SDS, $0.001 \%$ Bromophenol blue and $5 \% \beta$-mercaptoethanol, separated using a $12 \%$ Tris-Glycine gel (Laemmli 1970) and transferred to a nitrocellulose membrane. The $\mathrm{P} 2$ and $\mathrm{P} 3$ sub-cellular pellet fractions were further processed for transmission electron microscope using a method as described in Shanbhag et al. (1995). The P1 fraction was not processed for EM because at that $\mathrm{g}$ forces one would enrich nuclei and mitochondria and other broken contaminants.

\section{Immunological detection of ABPs}

The western blotting and detection was done essentially as described by Harlow and Lane (1988), with few modifications. The Western blots were incubated in 5\% fat-free

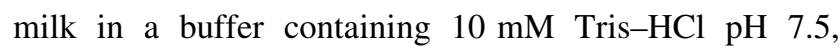
$50 \mathrm{mM}$ sodium chloride $(\mathrm{NaCl}), 2 \mathrm{mM}$ calcium chloride $\left(\mathrm{CaCl}_{2}\right)$ and $0.1 \%$ Tween 20 [milk-Tris Buffered SalineTween (TBS-T)] for $2 \mathrm{~h}$ at room temperature in order to block the non-specific binding sites. The primary polyclonal anti-ABP1 or monoclonal anti-KDEL or anti-HDEL antibodies were incubated in milk-TBS-T for $2 \mathrm{~h}$ at room temperature or overnight at $4^{\circ} \mathrm{C}$ on a shaker. Blots were washed four times, with milk-TBS-T and incubated with biotinylated anti-rabbit $\operatorname{IgG}$ (for anti-ABP1) or anti-mouse or rat IgG (for anti-KDEL and anti-HDEL) for $2 \mathrm{~h}$ at room temperature. Blots were developed using the $\mathrm{ABC}$ kit with di-aminobenzidine as a substrate (Vector laboratories, Burlingame, USA).

Preparation of extracts for photo-affinity labelling of ABPs

The microsomal membranes were prepared from the calcium promoted sedimentation of vesicles as described (Shimomura et al. 1986). The microsomal pellet (30 mg dry acetone powder) was suspended in $425 \mu$ of chilled photoaffinity labelling buffer containing $10 \mathrm{mM}$ citrate buffer $\mathrm{pH}$ 5.7, $5 \mathrm{mM} \mathrm{MgCl}{ }_{2}, 1 \mathrm{mM}$ phenylmethanesulphonylfluoride 
(PMSF) and homogenised for $20 \mathrm{~min}$ at $4^{\circ} \mathrm{C}$. The suspension was collected in a $1.5 \mathrm{ml}$ polypropylene tube, vortexed vigorously for $3 \mathrm{~min}$ and centrifuged at $18,000 \times \mathrm{g}$ for $5 \mathrm{~min}$. The pellet was again washed with $400 \mu \mathrm{l}$ of buffer, mixed thoroughly, vortexed for $5 \mathrm{~min}$ and used for photoaffinity labelling.

Photo-affinity labelling using 5 -azido $7-{ }^{3} \mathrm{H}$-indole 3-acetic acid

Photo-affinity labelling reaction was carried out as described in Jones and Venis (1989) and Jones et al. (1984), with little modifications. All steps prior to separation of the proteins on the gel were done in dim safe red light in a dark room as described in Jones et al. (1998). The photo-affinity labelling reaction was performed in a final volume of $120 \mu \mathrm{l}$. Thirty microlitres of labelling buffer $(200 \mathrm{mM}$ citrate $\mathrm{pH} 5.55,20 \mathrm{mM} \mathrm{MgCl}_{2}$ and $1 \%$ sodium cholate) and $80 \mu \mathrm{l}$ of protein suspension were pipetted into a $1.5 \mathrm{ml}$ polypropylene tube and kept at $4^{\circ} \mathrm{C}$. Azido-IAA $(0.33 \mu \mathrm{M}$ final) with or without non-radioactive IAA made in water in a final volume of $7 \mu \mathrm{l}$ was added and incubated for $30 \mathrm{~min}$ in dark at $4^{\circ} \mathrm{C}$. The mixture was then transferred to a glass cavity slide. The slide was kept on a platform maintained at $4{ }^{\circ} \mathrm{C}, 5 \mathrm{~cm}$ below the UV source. The contents of the slides were exposed to the UV source $(3 \times 254 \mathrm{~nm}$ and $2 \times 330 \mathrm{~nm}$ bulbs, Hofer UV transilluminator from HOFER Scientific) for $30 \mathrm{~s}$. The samples were frozen immediately in liquid nitrogen and kept at $20^{\circ} \mathrm{C}$ for $24 \mathrm{~h}$. Subsequently they were boiled with SDS sample buffer containing $62 \mathrm{mM}$ Tris $\mathrm{pH} 6.8,10 \%$ glycerol, $2 \%$ SDS, $0.001 \%$ bromophenol blue, $5 \% \beta$-mercaptoethanol, separated using $12 \%$ SDS-polyacrylamide gel electrophoresis (PAGE) and analysed by fluorography. For fluorography, the gels were washed in a mixture of $30 \%$ ethanol and $12 \%$ acetic acid for $2 \mathrm{~h}$. The solution was discarded and replaced with six volumes of infiltration solution (55\% acetic acid, 15\% ethanol, 30\% xylene and $0.5 \% \mathrm{PPO}$ ) and agitated for $1 \mathrm{~h}$ at room temperature. Care was taken to ensure that the gels were not sticking to the glass tray. The gels were washed two to three times in deionised water, dried and autoradiographed for 20-25 days at $-80^{\circ} \mathrm{C}$.

\section{Chemicals}

Anti-ABP1, anti-KDEL and anti-HDEL antibodies were generous gifts from Dr. Mike A. Venis and Dr. Richard M. Napier, HRI, Warwick, UK. The Avidin-Biotin amplification kit (ABC kit) was purchased from Vector laboratories, Burlingame, USA, while the PPO was obtained from Sisco chemical laboratories, India. 5-Azido $7-{ }^{3} \mathrm{H}-\mathrm{IAA}$ with $>99 \%$ radiochemical purity by radiochromatography according to Jones et al. (1984) was purchased from Dr. Alan M. Jones, North Carolina, Chapel Hill, USA. All other chemicals were obtained from Sigma Chemical Co.

Phylogeny of ABP1

A phylogenetic tree of ABP1 proteins was constructed using Neighbour Joining as implemented in quicktree (Howe et al. 2002) using the ScoreDist distance matrix (Sonnhammer and Hollich 2005), 1,000 bootstrap replicates and setting the root at the longest internal branch. It includes the ABP1 sequences of 13 land plants, which are indicated by a five letter code, as follows: Arath: Arabidopsis thaliana (Genbank: NP_192207), Avesa: Avena sativa (Genbank: BAA25433), Cerpu: C. purpureus (Genbank: AAF37576), Cerri: Ceratopteris richardii, Glyma: Glycine max, Medtr: Medicago truncatula, Orysa: Oryza sativa (Genbank: ABF85613), Phypa: P. patens (Cosmoss: Phypa_151546), Poptr: Populus tremula, Selmo: Selaginella moellendorffi, Sorbi: Sorghum bicolor, Vitvi: Vitis vinifera (Genbank: ACG80594), Zeama: Z. mays (Genbank: NP_001105312). Genbank accession numbers can be found on http://www. ncbi.nlm.nih.gov/, while for the other organisms following URLs were used:

\section{ftp://ftp.jgi-psf.org/pub/JGI_data/Glycine_max/ annotation/Glyma0.1b.pep.fa.gz}

http://www.medicago.org/genome/downloads/Mt2/ 20080103_imgag_proteinMAPPED_NO_OVERLAP.fa http://www.cosmoss.org

ftp://ftp.jgi-psf.org/pub/JGI_data/Poplar/annotation/ v1.1/proteins.Poptr1_1.JamboreeModels.fasta.gz

http://genome.jgi-psf.org/Selmo1/download/

Selmo1_GeneModels_FilteredModels2_aa.fasta.gz

ftp://ftp.jgi-psf.org/pub/JGI_data/Sorghum_bicolor/v1.0/ Sorbi1_GeneModels_Sbi1_4_aa.fasta.gz

Multiple sequence alignments of all 14 ABP1 sequences were created using MAFFT L-INSI (Katoh et al. 2005) and curated with Jalview (Clamp et al. 2004).

\section{Results}

${ }^{3} \mathrm{H}-\mathrm{IAA}$ binding to the microsomal membranes

Microsomal membranes from Funaria protonema were isolated and observed to exhibit specific auxin-binding sites. The specifically bound IAA was estimated to be 
between 3 and $5 \mathrm{pmol} / \mathrm{mg}$ of protein (Fig. 1). The ${ }^{3} \mathrm{H}$-IAA binding was decreased in a dose dependent manner by increasing the amounts of non-radioactive IAA in the incubation medium (Fig. 1). The binding of the ${ }^{3} \mathrm{H}$-IAA to the microsomal membranes was improved significantly (15-18-fold) by dialysing the membrane fraction (data not shown). The potential $\mathrm{Km}$ for IAA to its binding sites was determined to range in between 3 and $5 \mu \mathrm{M}$ (Fig. 1).

Detection of Funaria ABPs using anti-ABP1 antibodies

In order to identify the ABP1 homologue in Funaria, anti$\mathrm{ABP} 1$ antiserum raised against the purified corn ABP1 was used. The sodium cholate solubilised protein extracts of moss and corn were separated by SDS-PAGE and Western blots were probed with anti-ABP1 antiserum. In corn, which served as a positive control, the antisera crossreacted with polypeptides of 22 and $24 \mathrm{kDa}$, however, no polypeptide of similar molecular mass was detectable in the moss extracts. Strikingly, polypeptides of about 31-33 and $46 \mathrm{kDa}$ were detected in both plants tested (Fig. 2). Furthermore, the $31-33 \mathrm{kDa}$ region appears to contain at least two closely migrating polypeptides (Fig. 3). In order

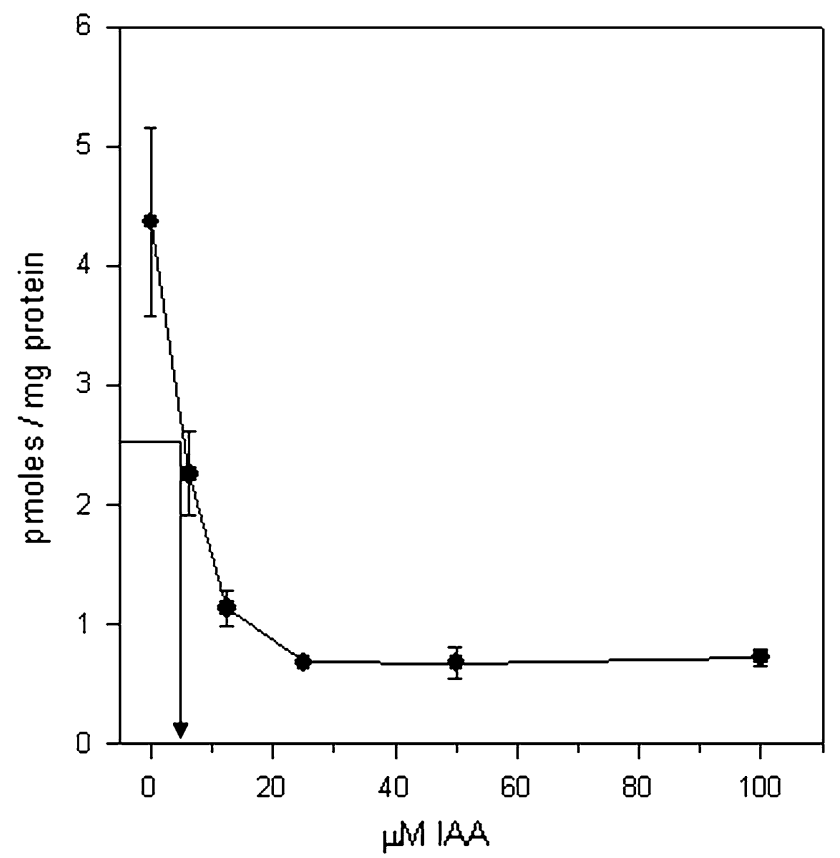

Fig. 1 Microsomal membranes from the moss Funaria hygrometrica were incubated on ice with $83 \mathrm{nM}{ }^{3} \mathrm{H}$ IAA for $30 \mathrm{~min}$ in dark followed by the addition of increasing concentrations of nonradioactive IAA $(0,6.25,12.5,25,50$ and $100 \mu \mathrm{M})$ in six different reaction tubes. The reaction mixture was filtered through cellulose acetate filters, washed with binding buffer and the radioactivity is determined. The standard deviation of triplicate filters was plotted as a function of concentration of IAA. The concentration corresponding to $\sim K_{\mathrm{m}}$ is shown by an arrow. The variation between samples by the filter assay was observed to be $<5 \%$

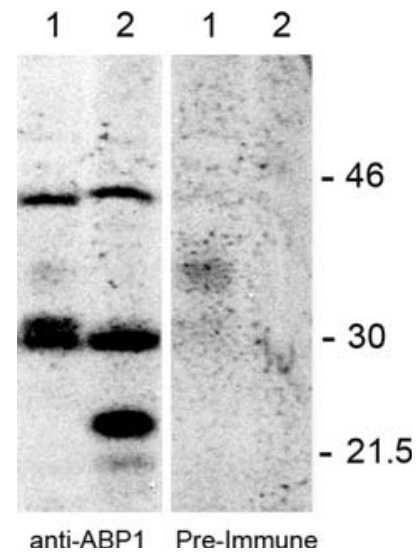

Fig. 2 Sodium cholate solubilised total proteins from moss (lane 1) and corn (lane 2) were resolved in 12\% SDS-PAGE, transferred to nitrocellulose filters and probed with anti-ABP1 antibodies or preimmune sera at a dilution of $1 / 1,000$

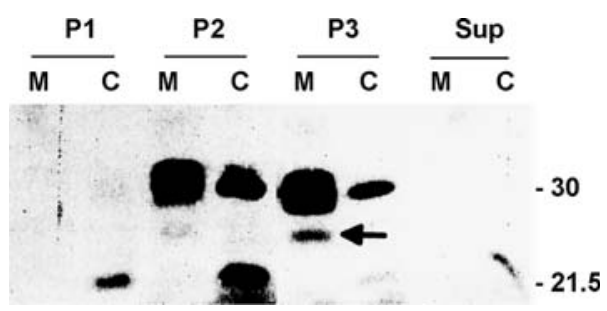

Fig. 3 Cell free extracts from moss $(M)$ and corn $(C)$ were fractionated by differential centrifugation to obtain various pellets $(P 1-P 3)$ and post-microsomal supernatant (Sup) as described in "Materials and methods". Proteins from the pellets were solubilised with $1 \%$ sodium cholate and $15 \mu \mathrm{g}$ of solubilised proteins from each sample were separated using $12 \%$ SDS-PAGE, transferred to nitrocellulose filters and probed with anti-ABP1 antibodies. A $28 \mathrm{kDa}$ putative ABP1 specific to $\mathrm{P} 3$ sub-cellular fraction of moss is marked by an arrow

to understand the localisation of these putative ABPs, we performed sub-cellular fractionation using differential centrifugation and probed the Western blots with antiABP1 antibodies (Fig. 3). This fractionation led to a significant enrichment of the 31-33 kDa polypeptides which were detected exclusively in the microsomal membrane fraction and resolved into two or three isoforms (Fig. 3). In addition, a $28 \mathrm{kDa}$ polypeptide was specifically detected in the P3 sub-cellular fraction of moss (Fig. 3, marked with an arrow). The particulate fractions of moss (Fig. 4a, b) and corn (Fig. 4c, d) were examined by transmission electron microscopy to ascertain the composition of the P2 (Fig. 4a, c) and P3 (Fig. 4b, d) fractions. In both plant species tested, examined fractions contained membranous vesicles. The vesicles in the $\mathrm{P} 2$ sub-cellular fractions were often found to be associated with high density dotted structures, presumably ribosomes (Fig. $4 \mathrm{a}, \mathrm{c}$ ). This also implies that the P2 sub-cellular fractions were enriched with vesicles that arose from the intact or broken ER. 

d) sub-cellular fractions of moss $(\mathbf{a}, \mathbf{b})$ and corn $(\mathbf{c}, \mathbf{d})$ were processed for transmission microscopy as described in "Materials and methods". The ER membrane vesicles and ribosomal dots are marked by arrows
Fig. 4 The P2 (a, c) and P3 (b,


These vesicles were more prominent in the P2 fraction compared to the P3. These results suggest that the putative ABPs may be associated with membranes and/or vesicles.

Immuno-precipitation using anti-KDEL monoclonal antibodies and detection using anti-ABP1 antiserum

Since the classical corn ABP1 is known to possess a Cterminal KDEL sequence and to be retained in the ER, it was investigated if any of the moss polypeptides sharing the immunological epitopes of ABP1 also possesses a KDEL epitope. Monoclonal antibodies raised against the KDEL sequence were used to immuno-precipitate proteins from the $\mathrm{P} 2$ sub-cellular fractions as described previously. Equal amounts of protein from the immuno-precipitated samples of moss and corn were either silver stained or transferred to a polyvinylidene fluoride (PVDF) membrane and probed with anti-ABP1 antiserum (Fig. 5). None of the 31-33 or $46 \mathrm{kDa}$ polypeptides was detected by the monoclonal antibody, while the $22-24 \mathrm{kDa} \mathrm{ABP} 1$ of corn was clearly detected (Fig. 5). These results suggest that the identified putative moss ABPs do not include a KDEL signal peptide sequence. It indicates further that the putative ABPs of higher molecular mass identified in corn and Funaria by Western blotting do not possess the ER retention signal, thus not being a mere finding in lower plants.
Fig. 5 Protein samples from the membrane enriched fractions of moss, Funaria hygrometrica $(M)$ and corn, Zea mays $(C)$ were immuno-precipitated using anti-KDEL monoclonal antibodies. The polypeptides were separated on a SDS gel and either stained by silver (left side of the marker) or probed on a Western blot using anti-ABP1 antiserum as described in "Materials and methods" 
Photo-affinity labelling using 5-azido 7-[ $\left.{ }^{3} \mathrm{H}\right]$-indole acetic acid

In order to determine if the putative moss ABP1 homologues with a size of $31-33$ and $46 \mathrm{kDa}$ identified in this study are capable of binding auxin, photo-affinity labelling using 5-azido-7- ${ }^{3} \mathrm{H}$-IAA was carried out with the microsomal membrane fractions under the conditions described in "Materials and methods". Binding of the radioactive azido-auxin to the microsomal fractions of moss also revealed the presence of two major polypeptides at 31-33 and $46 \mathrm{kDa}$ (Fig. 6). The specificity of this binding was evaluated by increasing the amounts of non-radioactive IAA in the reaction mixture prior to UV cross-linking as by such means the high-affinity binding sites would be outcompeted. The proteins were separated under denaturing conditions and signals from the gel were detected by fluorography. Strikingly, polypeptides of identical molecular masses, i.e. $31-33$ and $46 \mathrm{kDa}$, were intensively labelled by azido-auxin, although with different affinities (Fig. 6, lane 1). Upon competition with increasing amounts of non-radioactive IAA $(5-10 \mu \mathrm{M})$ in the reaction mixture (lanes 2-5) and prior to UV cross-linking, there was a complete disappearance of the azido-IAA labelling (Fig. 6, lanes 4, 5).

Phylogenetic analysis and sequence comparison of ABP1 in land plants

The topology of the phylogenetic tree for the 14 ABP1 proteins from 13 land plants (Fig. 7) confirms the evolutionary conservation of the protein sequence among mosses, as the ABP1 from P. patens and the one from C. purpureus

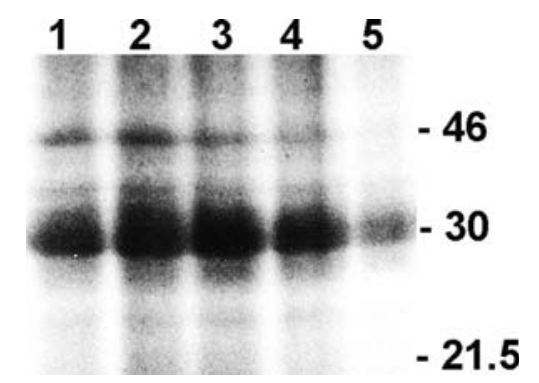

Fig. 6 Proteins from the acetone-washed microsomal vesicles of moss were solubilised in buffer as described in "Materials and methods". Equal amount of proteins from both buffer-soluble fraction and insoluble pellet were incubated with $0.33 \mu \mathrm{m}$ azido-IAA in the presence of increasing amount of non-radioactive IAA for $20 \mathrm{~min}$ under red safe light (lanes $1-5$ with $0 \mathrm{nM}, 100 \mathrm{nM}, 500 \mathrm{nM}, 2.5 \mu \mathrm{M}$ and $1 \mu \mathrm{M}$, respectively). The contents were exposed to UV light for $30 \mathrm{~s}$, denatured in SDS sample buffer, separated using 14\% SDSPAGE. The gels were washed, fluorographed and autoradiographed for 25 days at $-70^{\circ} \mathrm{C}$. Note the highest labelling of the $28 \mathrm{kDa}$ polypeptide in the particulate fraction cluster together. These species lack the classical C-terminal KDEL ER retention sequence that is found in all other land plants, neither do the moss sequences encode a derived ER retention signal [Prosite pattern PS00014, according to Andres et al. (1990)] (Fig. 8). The sequences for the ABP1 proteins from $S$. moellendorffii, as well as one from $P$. tremula (Poptr_ABP1-2) and from G. max are likely to be fragmentary which might explain why they do not depict the KDEL sequence.

\section{Discussion}

From an evolutionary viewpoint bryophytes (mosses and liverworts) are considered to be the earliest known land plants (Qiu et al. 1998, 1999; Lang et al. 2008). The study of hormone signalling in these organisms might hence be gaining attention in the scientific community as research on them might be the key to understand the possible origin of a primitive auxin sensing machinery (Johri 2004; Paponov et al. 2009). Protonema cells of Funaria were chosen in this study because they are highly responsive to physiologically relevant concentrations of exogenously applied auxin. In moss both developmental steps, chloronema proliferation and the differentiation to caulonema are under the regulation of auxin. Hence, as part of these processes basipetal transport as well as auxin-binding sites might be involved (Reski 1998). The present investigation of ABPs in Funaria using microsomal membrane fractions of this moss showed the presence of specific auxin-binding sites. The derived Km of IAA to its binding sites in Funaria and corn was comparable being in a physiological range of $3-$ $5 \mu \mathrm{M}$ (Hertel et al. 1972).

There are several ABPs described in different plants. The classical ER localised ABP1 of corn has drawn far more attention over the years. A small fraction of ABP1 (ca. $\sim 2 \%$ ) is localised to the plasma membrane where it has been shown to function in one of the early effects of auxin, i.e. hyper-polarisation of the membrane (Henderson et al. 1997; Barbier-Brygoo et al. 1989). Several lines of evidence is accumulating that suggest ABP1 might function in the plasma membrane and control a variety of events such as cell polarity, cell cycle, ion channels and sense cytoplasmic auxin gradients. These assign ABP1 as a possible candidate for a bonafide auxin receptor (Kramer 2009).

Among mosses, the $C$. purpureus ABP1 homologue possesses most of the conserved domains, however, it lacks the C-terminal ER retention sequence (Napier et al. 2002). The analysis of sequence data from the moss $P$. patens also leads to the identification of an ABP1 (Phypa_151546) although it does also not contain any ER retention sequence as well. The use of standard computational prediction 


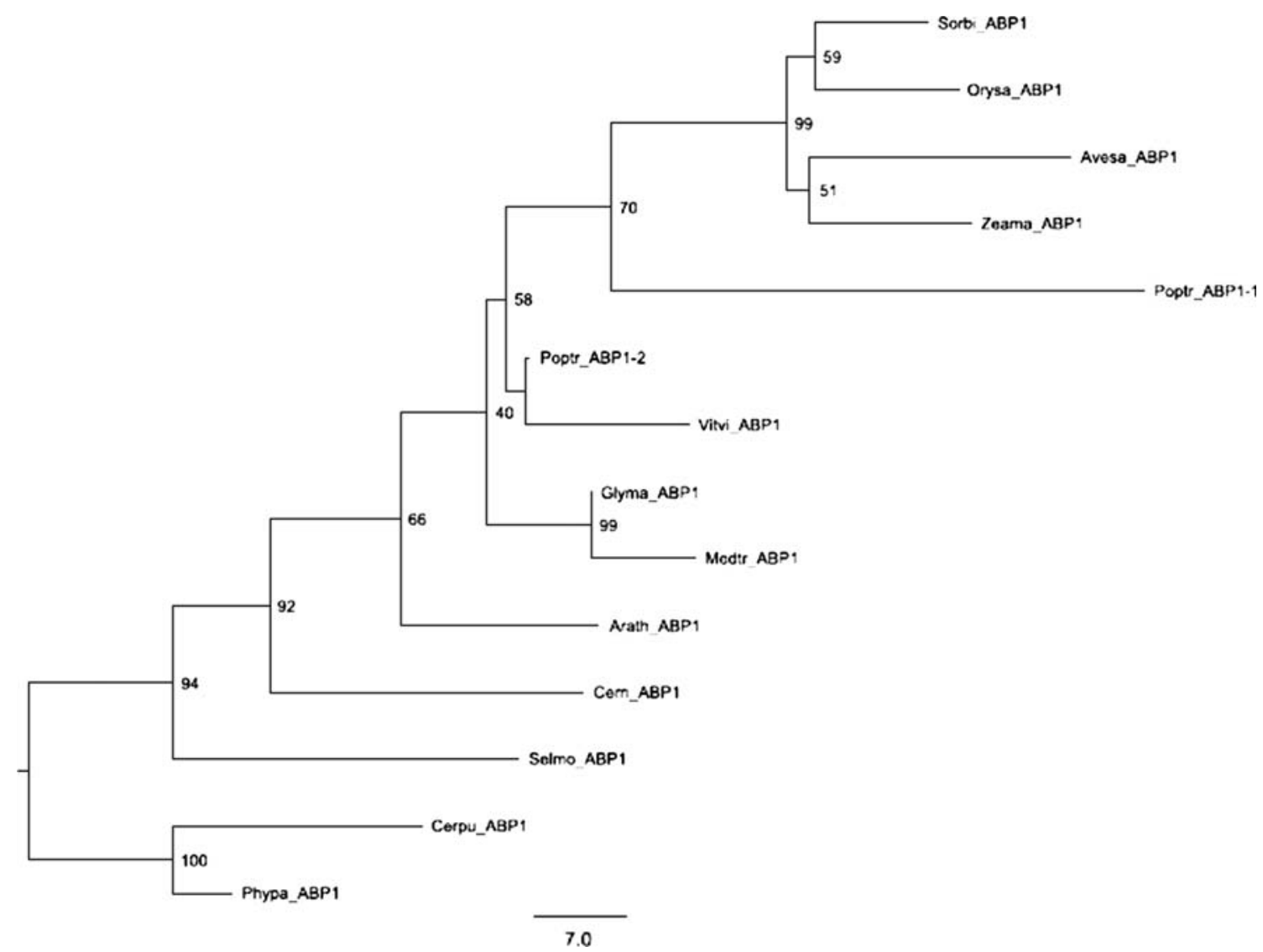

Fig. 7 Phylogenetic tree of ABP1 proteins among 13 land plants. The ABP1 sequences for each organism are indicated by a five letter code, as follows: Arath: Arabidopsis thaliana, Avesa: Avena sativa, Cerpu: Ceratodon purpureus, Cerri: Ceratopteris richardii, Glyma: Glycine max, Medtr: Medicago truncatula, Orysa: Oryza sativa, Phypa: Physcomitrella patens, Poptr: Populus tremula, Selmo: Selaginella

programmes [i.e. TargetP (Emanuelsson et al. 2000), SherLoc (Shatkay et al. 2007), MultiLoc (Hoglund et al. 2006), WoLF PSORT (Horton et al. 2007)] to localise this moss $\mathrm{ABP} 1$ homologous protein suggested that it is not localised to the ER (data not shown). It therefore seems possible that a true homologue of ABP1 with a classical KDEL ER retention sequence may not be present in mosses. Attempts were also made to investigate if the putative ABP1 homologues use HDEL as a signal sequence for its retention in the ER. The HDEL retention sequence is sufficient for secretory plant proteins to be retained in the ER while promoting vascular targeting of the proteins that escapes ER (Gomord et al. 1997). None of the putative ABPs were detected with the respective antibody, although as a positive control a $80 \mathrm{kDa}$ protein (most likely to be a Bip, binding protein, a member of HSP70 family and a major chaperone of ER) was detected in corn extracts (data not shown). There is a report from animal systems describing signal sequences such as DKEL, RDEL, KNEL to be used as the ER retention signal (Andres et al. 1990). moellendorffi, Sorbi: Sorghum bicolor, Vitvi: Vitis vinifera, Zeama: Zea mays. The phylogenetic tree was constructed using Neighbour Joining as implemented in quicktree (Howe et al. 2002) using the ScoreDist distance matrix (Sonnhammer and Hollich 2005), 1,000 bootstrap replicates and rooted at the longest internal branch

However, neither the $P$. patens nor the $C$. purpureus ABP1 nucleotide sequences contain such alternative retention signals. Moreover, there is a remarkable conservation between regulatory as well as signal sequences between moss and mammals (Schaaf et al. 2005; Gitzinger et al. 2009), making it unlikely that mosses contain hitherto unknown ER retention signals.

Therefore, it is tempting to suggest that the ER retention sequence of ABP1 in higher plants could have evolved independently and at a later stage along with the needs for a specialised auxin signalling during the evolution of higher land plants, as was recently described for the evolution of nuclear auxin signalling (Paponov et al. 2009). It is also possible that these proteins are functional homologues of higher plant ABP1 and control essential nonnuclear processes such as cell elongation, polarity and control of ion channels, fundamental to plant development. Not only in the moss Funaria, but also in the extracts of corn and sorghum (data not shown) higher molecular mass putative ABPs were detected in the current study by 
Fig. 8 Multiple amino acid sequence alignment of the auxin-binding protein $1(A B P 1)$ in land plants. Sequences were aligned using MAFFT L-INSI (Katoh et al. 2005). Black shaded boxes highlight identical residues. Grey shaded boxes mark similar residues. Gaps are marked by dashes in the alignment. Within the consensus line conserved amino acids are depicted in capital letters. The amino acids belonging to the KDEL retention sequence are highlighted by red squares

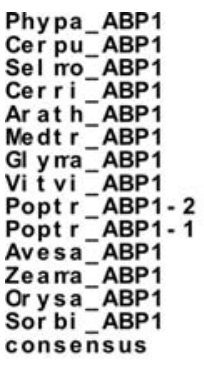

and ............... MARLACSFVLLVFLGF CFLARSSAL GNPGVCGKSEI PVVRLTE

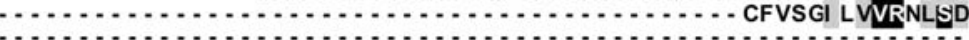
W . W. . . . . . . . . . . . VGI SI I FLI LSI L . . LSATAEASQCSAI GLPLVKKMTNE

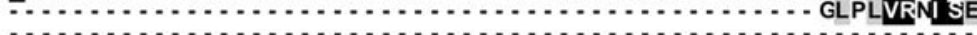
W- - ESRAGI AAAVRGLRFAGAGRRGTLLLALLFVAADAFLPVAEPSCPRDNSVVKDINO YAPDLSELAAAAPARGAYLAGVG........ VAVLLAASFLPVAESSCVRDNSLVFDI SG ETRT GPTAAVAAGGGAHLACAG- RGALLLALVAVAAAVFLPVTESSCPRDNSL VRDVSK $\frac{\pi}{\pi}-$ - VRELPAAGAARGPHLAAVG- - RGLLLAALLVAAASFLPVAESSCPRDNSLVR 1. . . . 10. . . 20 .

40 0 .

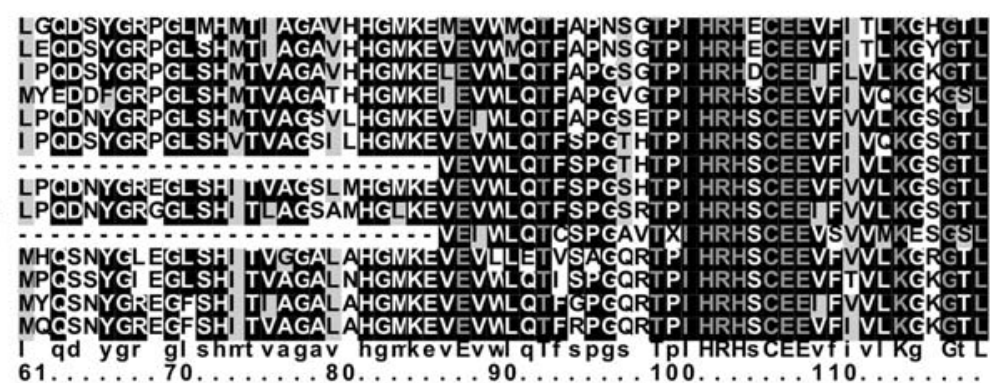

\begin{tabular}{|c|c|}
\hline $\begin{array}{l}\text { Cerpu- } \\
\text { Sel mo- } \\
\text { Cerri- } \\
\text { Arath- } \\
\text { Nedtr- } \\
\text { Gl y ra- } \\
\text { Vit tivi- } \\
\text { Poptr- } \\
\text { Poptr } \\
\text { Avesa- } \\
\text { Zearra- } \\
\text { Orysa- } \\
\text { Sorbi- } \\
\text { consen }\end{array}$ & $\begin{array}{l}\text { ABP1 } \\
\text { ABP1 } \\
\text { ABP1 } \\
\text { ABP1 } \\
\text { ABP1 } \\
\text { ABP1 } \\
\text { ABP1 } \\
\text { ABP1 } \\
\text { ABP1-2 } \\
\text { ABP1-1 } \\
\text { ABP1 } \\
\text { ABP1 } \\
\text { ABP1 } \\
\text { ABP1 } \\
\text { ABP1 } \\
\text { A }\end{array}$ \\
\hline
\end{tabular}

Phypa_ABP1 Cer pu_ABP1 Sel rro_ABP Cerri_ABP Ar at h-ABP Nedt $r_{-}^{-}$ABP $\mathrm{Gl}$ y ra-ABP Vi t vi - ABP1 Popt $r_{-}^{-}$ABP1 - 2 Popt $r$ - ABP1Avesa-ABP1 Zearra_ABP1 Or ysa_ABP1 Sor bi ${ }^{-A B P 1}$ conseñsus

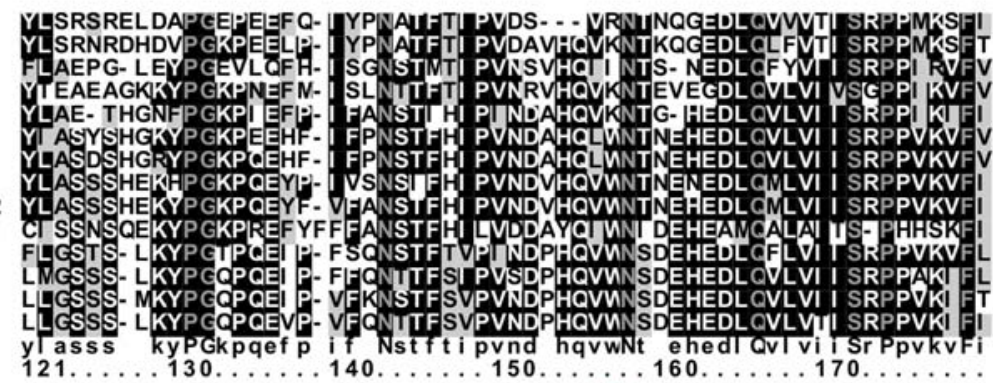

Phypa_ABP Cer pu_ABP Sel mo_ABP Cerri-ABP Ar at $h^{-} \mathrm{ABP}$ Nedt $r$-ABP Gl y ra-ABP1 Vit vi -ABP1 Popt $r_{-}^{-} A B P 1$ - 2 Popt $r$ _ABP1 1 Avesa_ABP Zearra_ABP Orysa-ABP Sor bi ${ }^{-} \mathrm{ABP}$ conseñsus

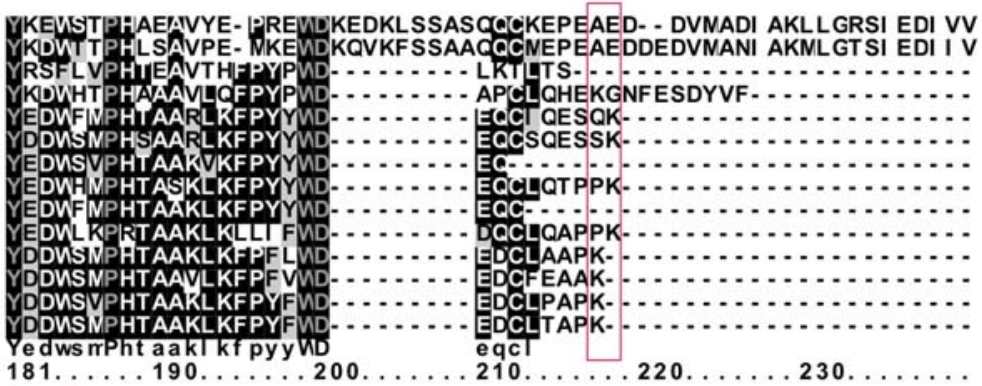



anti-ABP1 antibodies, nicely confirming earlier findings on corn (Jones and Venis 1989). This result suggests that there are other ABP1-related proteins or proteins sharing epitopes with ABP1 and which are present not only in Funaria but also in higher land plants. These proteins might be part of the auxin metabolising enzymes or transporters presumably being conserved across species, like the $\mathrm{GH} 3$ proteins (Ludwig-Müller et al. 2009). Based on these results, it is also tempting to speculate that these proteins may be the molecular imprint of a primitive auxin sensing machinery. Retention of these proteins in the ER of vascular plants may have evolved much later as a safeguard 
storage mechanism in order to ensure a continuous supply of this to the plasma membrane. This suggestion is supported by the observation that ABP1 does not bind auxin in the lumen of the ER despite this being the predominant sub-cellular location (Tian et al. 1995).

It is also interesting in this respect to note that two distinct signalling pathways of auxin action have been described in the epidermal cells of pea (Pisum sativum): the ABP1-dependent pathway, which has higher sensitivity to NAA and is independent of extracellular $\mathrm{Ca}^{2+}$ and the ABP1-independent pathway, which shows higher sensitivity to IAA and is dependent on extracellular $\mathrm{Ca}^{2+}$ (Yamagami et al. 2004). Since Funaria responds to IAA much better than NAA and grows better in calcium rich soil, it is tempting to suggest that the ABP1-independent mechanism seems to have evolved earlier than the ABP1dependent one. The plasma membrane bound ABPs have been found in plants earlier with the ones of Zucchini displaying a molecular mass of $40-42 \mathrm{kDa}$ (Hicks et al. 1993) and showing to be photo-affinity labelled by azidoauxin (Hicks et al. 1989). Therefore, the putative ABPs detected in the microsomal fraction appear to be associated with the plasma membrane (Fig. $4 \mathrm{~b}$, d). However, more work, like in vivo targeting of GFP-fusion proteins (Schaaf et al. 2004), is required to establish their precise localisation as it is also conceivable that plants have variable amounts of classical ABP1 proteins. The lack of detection of the classical $22 \mathrm{kDa} \mathrm{ABP} 1$ protein with an ER retention signal in Funaria does not appear to be a result of lower expression or abundance. Even after loading about 15-20 times more protein from moss than from corn, and even after several fold enrichment by subcellular fractionation, a polypeptide comparable to ABP1 was not detectable in our recent study. The $28 \mathrm{kDa}$ polypeptide detected in the $\mathrm{P} 3$ sub-cellular fraction of Funaria (Fig. 3 marked with an arrow) could be most likely the result of protein degradation specific to $\mathrm{P} 3$ fraction.

In summary, evidence is provided here for the presence of additional immunologically related ABP1 homologues in the moss Funaria that do not show the presence of the classical ER retention KDEL signal sequence. As sequence comparisons with other mosses confirm the lack of the retention signal in the $\mathrm{ABP} 1$ of mosses it is postulated that such a signal might have evolved during later stages of evolution in land plants, a feature that has recently been described for nuclear auxin signalling (Paponov et al. 2009) and for gibberellin signalling (Vandenbussche et al. 2007).

Acknowledgments We thank Prof. Mike A. Venis and Dr. Richard M. Napier, HRI, UK for providing the anti-ABP1, anti-KDEL and anti-HDEL antibodies. Additionally, acknowledge Dr. Karen Hicks and Dr. Amaury de Montaigu for discussions on the results. Moreover, we are thankful to Dr. Jacinta S. D'Souza for maintaining the cell line and Dr. Mark von Stackelberg for providing some moss $F$. hygrometrica. Special thanks to Prof. Eberhard Schaefer and Prof. George Coupland for their continued support. This research was supported by Deutsche Forschungsgemeinschaft (grant Re837/10) and by the Excellence Initiative of the German Federal and State Governments (EXC 294). Substantial work for this publication was carried out by K. P. as graduate student in the Department of Biological Sciences, Tata Institute of Fundamental Research, Mumbai, India.

Open Access This article is distributed under the terms of the Creative Commons Attribution Noncommercial License which permits any noncommercial use, distribution, and reproduction in any medium, provided the original author(s) and source are credited.

\section{References}

Andres DA, Dickerson IM, Dixon JE (1990) Variants of the carboxylterminal KDEL sequence direct intracellular retention. J Biol Chem 265:5952-5955

Badescu GO, Napier RM (2006) Receptors for auxin: will it all end in TIRs? Trends Plant Sci 11:217-223

Barbier-Brygoo H, Ephritikhine G, Klämbt D, Ghislain M, Guern J (1989) Functional evidence for an auxin receptor at the plasmalemma of tobacco mesophyll protoplasts. Proc Natl Acad Sci USA 86(3):891-895

Barbier-Brygoo H, Ephritikhine G, Maurel C, Guern J (1992) Perception of the auxin signal at the plasma membrane of tobacco mesophyll protoplasts. Biochem Soc Trans 20:59-63

Benjamins R, Scheres B (2008) Auxin: the looping star in plant development. Annu Rev Plant Biol 59:443-465

Bhatla SC, Kiessling J, Reski R (2002) Observation of polarity induction by cytochemical localization of phenylalkylaminebinding receptors in regenerating protoplasts of the moss Physcomitrella patens. Protoplasma 219:99-105

Bierfreund N, Reski R, Decker EL (2003) Use of an inducible reporter gene system for the analysis of auxin distribution in the moss Physcomitrella patens. Plant Cell Rep 21:1143-1152

Christian M, Steffens B, Schenck D, Lüthen H (2003) The diageotropica mutation of tomato disrupts a signalling chain using extracellular auxin binding protein 1 as a receptor. Planta 218:309-314

Clamp M, Cuff J, Searle SM, Barton GJ (2004) The Jalview Java alignment editor. Bioinformatics 20:426

Cooke TJ, Poli DB, Sztein E, Cohen JD (2002) Evolutionary patterns in auxin action. Plant Mol Biol 49:319-338

David KM, Couch D, Braun N, Brown S, Grosclaude J, PerrotRechenmann C (2007) The auxin-binding protein 1 is essential for the control of cell cycle. Plant J 50:197-206

Davies PJ (1995) Plant hormones physiology, biochemistry and molecular biology. Kluwer, Dordrecht, pp 1-12

Decker EL, Frank W, Sarnighausen E, Reski R (2006) Moss systems biology en route: phytohormones in Physcomitrella development. Plant Biol 8:397-406

Dharmasiri S, Estelle M (2002) The role of regulated protein degradation in auxin response. Plant Mol Biol 49:401-409

Dharmasiri N, Dharmasiri S, Estelle M (2005) The F-box protein TIR1 is an auxin receptor. Nature 435:441-445

Emanuelsson O, Nielsen H, Brunak S, von Heijne G (2000) Predicting subcellular localization of proteins based on their N-terminal amino acid sequence. J Mol Biol 300:10051016

Evans LV, Trewavas AJ (1991) Is algal development controlled by plant growth substances? J Phycol 27:322-326 
Gehring CA, McConchie RM, Venis MA, Parish RW (1998) Auxinbinding-protein antibodies and peptides influence stomatal opening and alter cytoplasmic pH. Planta 205:581-586

Gitzinger M, Parsons J, Reski R, Fussenegger M (2009) Functional cross-kingdom conservation of mammalian and moss (Physcomitrella patens) transcription, translation and secretion machineries. Plant Biotechnol J 7:73-86

Gomord V, Denmat LA, Fitchette-Lainé AC, Satiat-Jeunemaitre B, Hawes C, Faye L (1997) The C-terminal HDEL sequence is sufficient for retention of secretory proteins in the endoplasmic reticulum (ER) but promotes vacuolar targeting of proteins that escape the ER. Plant J 11(2):313-325

Harlow Ed, Lane D (1988) Antibodies: a laboratory manual, chap 12. CSHL press, New York

Henderson J, Bauly JM, Ashford DA, Oliver SC, Hawes CR, Lazarus CM, Venis MA, Napier RM (1997) Retention of maize auxinbinding protein in the endoplasmic reticulum: quantifying escape and the role of auxin. Planta 202:313-323

Hertel R, Thomson KS, Russo VAE (1972) In vitro auxin binding to particulate cell fractions from corn coleoptiles. Planta 107:325340

Hicks GR, Rayle DL, Jones AM, Lomax TL (1989) Specific photoaffinity labeling of two plasma membrane polypeptides with an azido-auxin. Proc Natl Acad Sci USA 86:4948-4952

Hicks GR, Rice MS, Lomax TL (1993) Characterisation of auxinbinding proteins from zucchini plasma membrane. Planta 189:83-90

Hoglund A, Donnes P, Blum T, Adolph HW, Kohlbacher O (2006) MultiLoc: prediction of protein subcellular localization using Nterminal targeting sequences, sequence motifs and amino acid composition. Bioinformatics 22:1158-1165

Horton P, Park KJ, Obayashi T, Fujita N, Harada H, Adams-Collier CJ, Nakai K (2007) WoLF PSORT: protein localization predictor. Nucleic Acids Res 35(Web Server issue):W585-W587

Howe K, Bateman A, Durbin R (2002) QuickTree: building huge Neighbour-Joining trees of protein sequences. Bioinformatics 18:1546-1547

Johri MM (1974) Differentiation of caulonema cells by auxin in suspension cultures of Funaria hygrometrica. In: Plant growth substances. Hirokawa Publishing, Tokyo, pp 925-933

Johri MM (2004) Possible origin of hormonal regulation in green plants. Proc Indian Natl Acad Sci B70:335-365

Johri MM (2008) Hormonal regulation in green plant lineage families. Physiol Mol Biol Plants 14:23-38

Johri MM, D'Souza JS (1990) Auxin regulation of cell differentiation in moss protonema. In: Pharis RP, Rood S (eds) Plant growth substances. Springer, Berlin, pp 407-418

Johri MM, Desai S (1973) Auxin regulation of caulonema formation in moss protonema. Nat New Biol 245:223-224

Jones AM, Herman EM (1993) KDEL-containing auxin-binding protein is secreted to the plasma membrane and cell wall. Plant Physiol 101:595-606

Jones AM, Venis MA (1989) Photoaffinity labeling of indole-3-acetic acid-binding proteins in maize. Proc Natl Acad Sci USA 86(16):6153-6156

Jones AM, Melhado LL, Ho TH, Pearce CJ, Leonard NJ (1984) Azido auxins: photoaffinity labeling of auxin-binding proteins in maize coleoptile with tritiated 5-azidoindole-3-acetic acid. Plant Physiol 75(4):1111-1116

Jones AM, Im KH, Savka MA, Wu MJ, DeWitt NG, Shillito R, Binns AN (1998) Auxin-dependent cell expansion mediated by over-expressed auxin-binding protein 1 . Science 282:11141117

Katoh K, Kuma K, Toh H, Miyata T (2005) MAFFT version 5: improvement in accuracy of multiple sequence alignment. Nucleic Acids Res 33:511-518
Kepinski S, Leyser O (2005) The Arabidopsis F-box protein TIR1 is an auxin receptor. Nature 435:446-451

Kramer EM (2009) Auxin-regulated cell polarity: an inside job? Trends Plant Sci 14(5):242-247

Laemmli UK (1970) Cleavage of structural proteins during the assembly of the head of bacteriophage T4. Nature 227:680-685

Lang D, Zimmer AD, Rensing SA, Reski R (2008) Exploring plant biodiversity: the Physcomitrella genome and beyond. Trends Plant Sci 13:542-549

Leblanc N, Perrot-Rechenmann C, Barbier-Brygoo H (1999) The auxin-binding protein Nt-ER abp1 alone activates an auxin-like transduction pathway. FEBS Lett 449:57-60

Ludwig-Müller J, Jülke S, Bierfreund NM, Decker EL, Reski R (2009) Moss (Physcomitrella patens) GH3 proteins act in auxin homeostasis. New Phytol 181:323-338

Napier RM, David KM, Perrot-Rechenmann C (2002) A short history of auxin-binding proteins. Plant Mol Biol 49:339-348

Oliver SC, Venis MA, Freedman RB, Napier RM (1995) Regulation of synthesis and turnover of maize auxin-binding protein and observations on its passage to the plasma membrane: comparisons to maize immunoglobulin-binding protein cognate. Planta 197:465-474

Oono Y, Ooura C, Rahman A, Aspuria ET, Hayashi K, Tanaka A, Uchimiya H (2003) p-Chlorophenoxyisobutyric acid impairs auxin response in Arabidopsis root. Plant Physiol 133:11351147

Paponov IA, Teale W, Lang D, Paponov M, Reski R, Rensing SA, Palme K (2009) The evolution of nuclear auxin signalling. BMC Evol Biol 9:126

Qiu YL, Cho Y, Cox JC, Palmer JD (1998) The gain of three mitochondrial introns identifies liverworts as the earliest land plants. Nature 394:671-674

Qiu YL, Lee J, Bernasconi-Quadroni F, Soltis DE, Soltis PS, Zanis M, Zimmer EA, Chen Z, Savolainen V, Chase MW (1999) The earliest angiosperms: evidence from mitochondrial, plastid and nuclear genomes. Nature 402:404-407

Quint M, Gray WM (2006) Auxin signaling. Curr Opin Plant Biol 9:448-453

Reski R (1998) Development, genetics and molecular biology of mosses. Bot Acta 111:1-15

Rose S, Bopp M (1983) Uptake and polar transport of indoleacetic acid in moss rhizoids. Physiol Plant 58:57-61

Schaaf A, Reski R, Decker EL (2004) A novel aspartic proteinase is targeted to the secretory pathway and to the vacuole in the moss Physcomitrella patens. Eur J Cell Biol 83:145-152

Schaaf A, Tintelnot S, Baur A, Reski R, Gorr G, Decker EL (2005) Use of endogenous signal sequences for transient production and efficient secretion by moss (Physcomitrella patens) cells. BMC Biotechnol 5:30

Schween G, Gorr G, Hohe A, Reski R (2003) Unique tissue-specific cell cycle in Physcomitrella. Plant Biol 5:50-58

Shanbhag SR, Singh K, Singh RN (1995) Fine structure and primary sensory projections of sensilla located in the sacculus of the antenna of Drosophila melanogaster. Cell Tissue Res 282:237249

Shatkay H, Hoglund A, Brady S, Blum T, Donnes P, Kohlbacher O (2007) SherLoc: high-accuracy prediction of protein subcellular localization by integrating text and protein sequence data. Bioinformatics 23:1410-1417

Shimomura S (2006) Identification of a glycosylphosphatidylinositolanchored plasma membrane protein interacting with the $\mathrm{C}$ terminus of auxin-binding protein 1: a photoaffinity crosslinking study. Plant Mol Biol 60:663-677

Shimomura S, Sotobayashi T, Futai M, Fukui T (1986) Purification and properties of an auxin-binding protein from maize shoot membranes. J Biochem 99:1513-1524 
Sonnhammer EL, Hollich V (2005) Scoredist: a simple and robust protein sequence distance estimator. BMC Bioinformatics 6:108

Sztein AE, Cohen JD, de la Fuente IG, Cooke TJ (1999) Auxin metabolism in mosses and liverworts. Am J Bot 86:1544-1555

Sztein AE, Cohen JD, Cooke TJ (2000) Evolutionary patterns in the auxin metabolism in green plants. Int J Plant Sci 161:849-859

Tian H, Klämbt D, Jones AM (1995) Auxin-binding protein 1 does not bind auxin within the endoplasmic reticulum despite this being the predominant subcellular location for this hormone receptor. J Biol Chem 270(45):26962-26969

Vandenbussche F, Fierro AC, Wiedemann G, Reski R, Van Der Straeten D (2007) Evolutionary conservation of plant gibberellin signalling pathway components. BMC Plant Biol 7:65
Weijers D, Jurgens G (2005) Auxin and embryo axis formation: the ends in sight? Curr Opin Plant Biol 8:32-37

Willemsen V, Scheres B (2004) Mechanisms of pattern formation in plant embryogenesis. Annu Rev Genet 38:587-614

Woo EJ, Marshall J, Bauly J, Chen JG, Venis M, Napier RM, Pickersgill RW (2002) Crystal structure of auxin-binding protein 1 in complex with auxin. EMBO J 21:2877-2885

Yamagami M, Haga K, Napier RM, Iino M (2004) Two distinct signaling pathways participate in auxin-induced swelling of pea epidermal protoplasts. Plant Physiol 134:735-747 